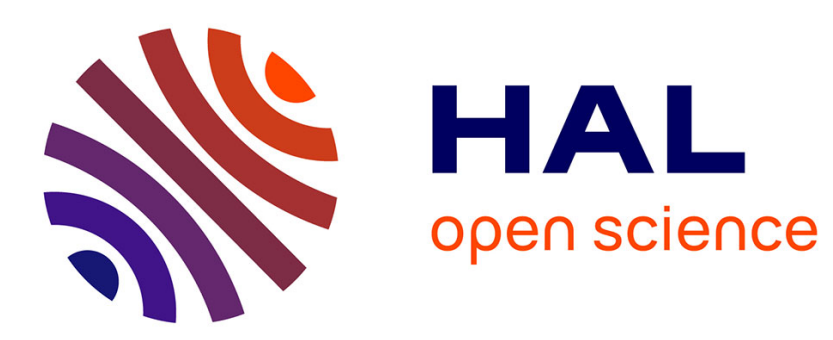

\title{
Taste perception and feeding behavior in non-human primates and human populations
}

\author{
Claude Marcel Hladik, Bruno Simmen
}

\section{To cite this version:}

Claude Marcel Hladik, Bruno Simmen. Taste perception and feeding behavior in non-human primates and human populations. Evolutionary Anthropology, 1996, 5, pp.58-71. hal-00556390

\section{HAL Id: hal-00556390 \\ https://hal.science/hal-00556390}

Submitted on 10 Jan 2013

HAL is a multi-disciplinary open access archive for the deposit and dissemination of scientific research documents, whether they are published or not. The documents may come from teaching and research institutions in France or abroad, or from public or private research centers.
L'archive ouverte pluridisciplinaire HAL, est destinée au dépôt et à la diffusion de documents scientifiques de niveau recherche, publiés ou non, émanant des établissements d'enseignement et de recherche français ou étrangers, des laboratoires publics ou privés. 


\section{Taste Perception and Feeding Behavior in Nonhuman Primates and Human Populations}

\author{
CLAUDE MARCEL HLADIK AND BRUNO SIMMEN
}

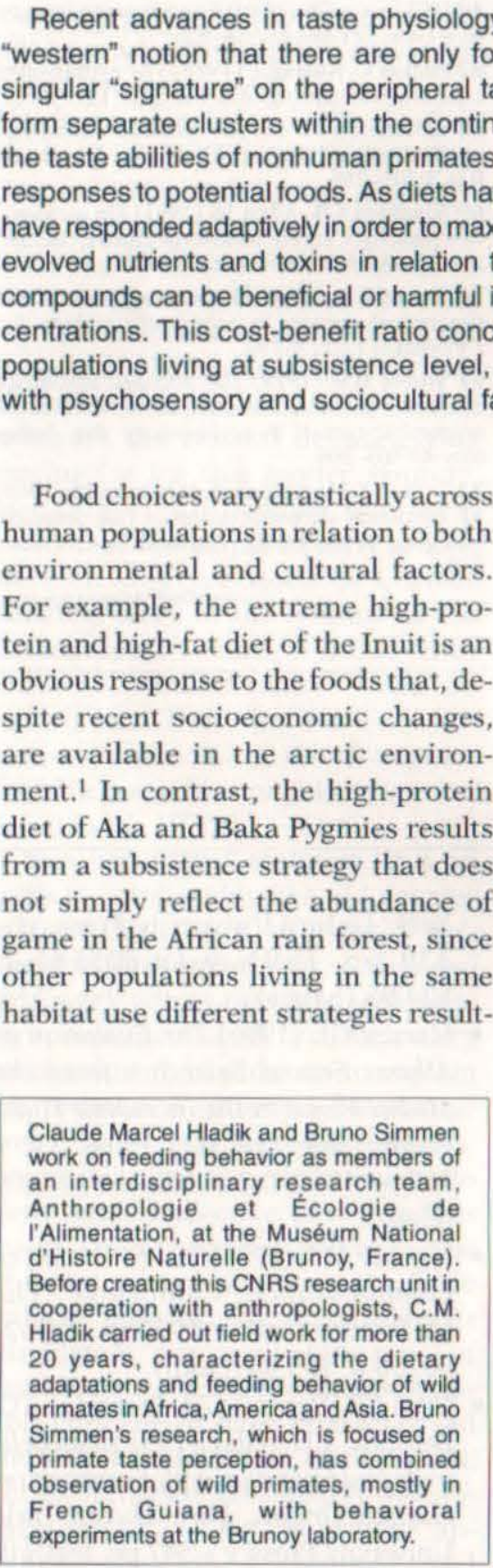

Key words: sugar perception, taste aversion, sat
perception, forest populations, taste acuity Most foods activate tems. The resulting perceptions are simultaneous and cannot easily be separated. For example, the volatile compounds of an orange stimulate the pharynx), whereas the soluble substances of the juice, in contact with th lingual mucosa, elicit a sweet-sour "taste" resignates the odor feeling even including to trigeminal (injitation from strong acid or chili), and thermal perceptions. There is evidence that such merged Homo sapiens. Indeed, single neuron cleus of the solitary tract) are activated by odor as well as by taste stimuli." Even color can change the quality of flavor. For example, uncololfactory, and gustatory neural pathways channeled towand the integrative cortical structures ${ }^{8}$ obviously contributes to a global perception of food.

However, when considering the taste signal alone, it is necessary to avoid misconceptions. The concept o four basic taste qualities has been laid to rest by many scientists, beginning with Schiffman and Erickson ${ }^{9}$ an descriptors that are common to several societies but they do not have a clear-cut physiological basis. Several substances, such as liquorice, canno be associated with any of these simple descriptors. ${ }^{12}$ However, the theory that there are only four basic tast qualities - an idea that was prevalen for half a century and still is advo cated 13 -led to the design of experirespond more strongly to sugars and within the mammalian brainstem (nuored orange juice is perceived as being Faumess, ments to show, for example, that som

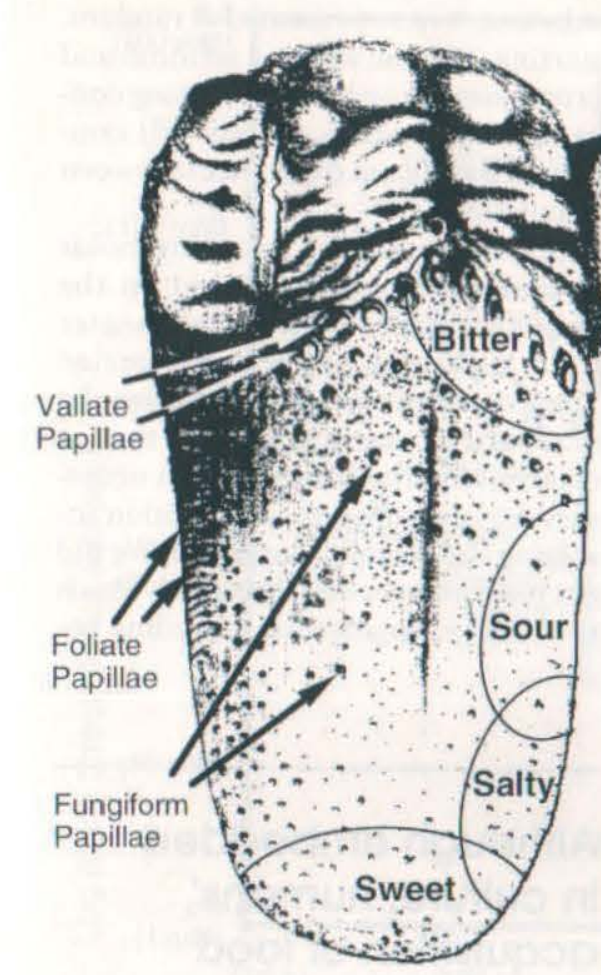

ess according to the stereochemic structure of the substance being can provide a clear-cut psychosensory image in humans," especially when cases, and pong. But in many cases, and particularly at low concen-
trations (when the shape of the signal is incomplete), it is difficult to disis inate among substances eliciting salt, at low concentration, evokes taste close to that of sugar..$^{10}$ When measuring thresholds, it is crucial no to ignore this complex build-up of the gustatory signal.

There are, nevertheless, categories of substances (e.g. sugars and acids) lar shapes that it is not easy sincriminate among different products within each category even at high concentration. The occurrence of such classes of tasty substances amo natural products is related to evolutionary trends in food nutrient conten and toxicity. The limited number of semantic descriptors in most language also reflects these taste spaces with the familiar terms of swet, we use ter, and salty, bearing in sori, bithese taste qualities are not diseret entities.

PSYCHOSENSORY RESPONSES

The most spectacular response elicited by tasting, the gusto-facial reflex, (Fig, 3), as well as newborn non-human primates. ${ }^{20}$ Neonates react in stereotyped ways, either rejecting bitter solutions with a typically arched form of the mouth or by accepting sugar solutions by sucking with a relaxed facial expression. As Steiner by a slight smile looks like an sion of satisfaction. During bexavres. development ${ }^{21}$ this response is generally reinforced by parental smiles, nonverbal form of communicatio that contributes to the pleasure of food perception and its variation.

in behavioral terms, the affective value (likes or dislikes) attributed to food tastes can be considered a sensory reward ${ }^{2}$ that eventually involve

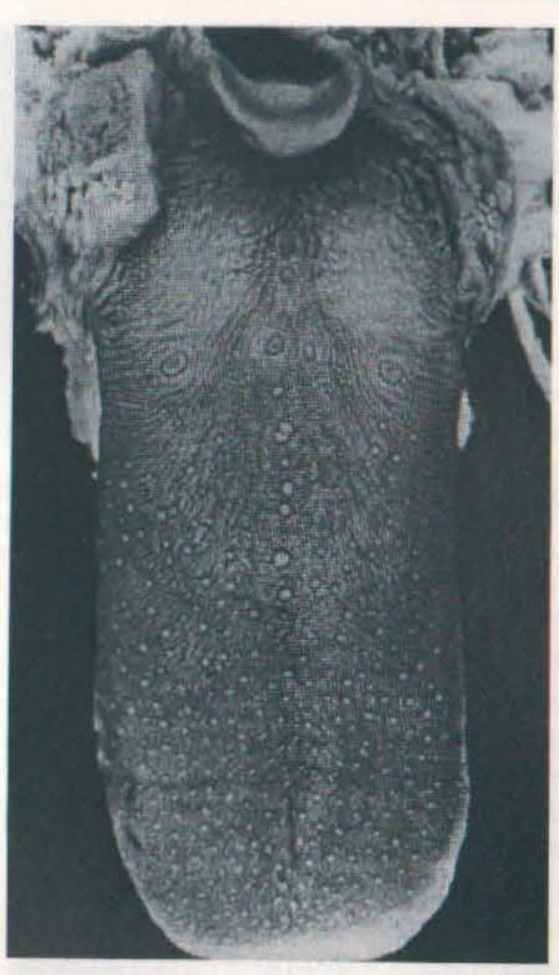

Figure 2 . The tongue of a chimponzee shows
distribution of paplilloe differing from that on the

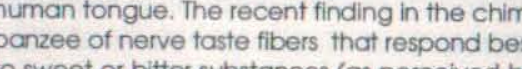
Dosweet or bitter substances (as perceived by
humans) suggests that some areas of the ongue could be differentiated in terms of local

phases following ingestion: 1 . Sen sory-specific satiety is a rapid varof one food item that occurs before any gastric satiation can be felt. ${ }^{24}$ I macaques, extreme specificity towar one food type corresponds to inhibitory responses of single neurons of the orbito-frontal cortex ${ }^{25}$ that do not oc cur for other food types. 2. Alliesthesia is a midale-term variation of the affective value of food taste that result chemoreceptors by the food ingested. ${ }^{26}$ This mechanism is less specific than the previous one because various alimentary tastes-cum-odor are affected simultaneously.27 3 . The ong-term response of hunger versus
satiety, which is related to a decrease in blood glucose, ${ }^{28}$ also influences ood pleasantness. ${ }^{29}$ All these mechanisms affecting the sensory reward asWithout the fod taste are necessary. Without the short-term sensory-spe could eat too much before the blood 


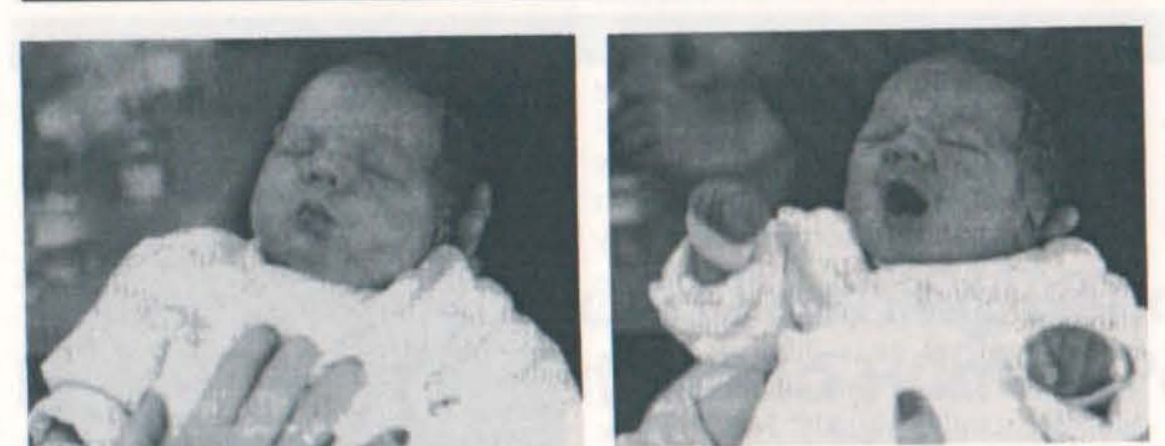

substances were presented at random, progressing in order of increasing concentration. Statistical tests $\left(x^{2}\right)$ confirmed significant differences between

populations ${ }^{37.38}$ several studies of taste thresholds
. in humans have been based on the ability to differentiate plain water These tests have aimed at detecting the onset of the taste signal, rather than at determining the concentration necessary for unambiguous recognition involving the overall taste signal. We did not use this detection thres s of minor importance in feeding be-

Figure 3 . Illustration of the gusto-facial reflex of a young baby. A relaxed face (left) follows tongue
contact with a sugar solution, whereas contact with quinine produces a strong relection reflex (right). These responseses imply separated projections of so

glucose reached a normal level,,$^{30}$ or drink excessively before osmoreceptor

signals prevent a dangerous dilution of
internal fluids ${ }^{31}$ In addition to genetically determined mechanisms, learning procfsses also intlence the perception of teractions between physiology and behavior is conditioned taste aversion. Garcia and Koelling ${ }^{32}$ showed that aversion to a particular taste can be artificially induced by a single experence of nausea following ingestio This efficient conditioning process can be viewed as an emergency syster for short-circuiting the successive an partly overlapping mechanisms th regulate food intake in mammals. Conversely, a progressive change that initilly consumed a highly palatable but nutritionally poor diet: whe distasteful but nutritious food wa made available, the animals learned prefer it after only a few days."

Such learning processes are prevalent during the exploratory phase development. ${ }^{34}$ Young children, after watching a respected older child eat particular dish, may subsequently initily profer it In adults, a simila social response occurs independently of the nutritional or health virtues the products ingested. In several socie ties, this could be called the beer-and-tobacco syndrome. Although embedded in culture, humans acquisition of food likes or dislikes is comparable to condtioned taste responses in other ma mals. Being part of a social group can be raise as much aversion as the nausea provoked by noxious food

\section{INVESTIGATING PRIMATE TASTE}

Methods used in the study of prnate taste perception must be adapted to the recent advances in the field of thaste physiology mentioned eartier. cons in the pychosensory processes.

In nonhuman primates, tast resholds, as well as profiles of suprathreshold ingestive responses, can b method, the two-bottle test adapted or statistical analysis. ${ }^{35}$ In this test the tastant solution and tap water are presented simultaneously to a monkey. Consumption of both liquids is at what concentration level the monkey shows preference or avoidance of the tastant. Although it has been found that the behavioral thresholds of some cording signals on a peripheral taste nerve, heseresults must be carefully interpreted because the test provides tion and preference.

contrast, experiments on humans have been focused on discriminativ taste of various substances. Tastan such as glucose, fructose, sucrose, sodium chloride, citric and oxalic acids. quinine hydrochloride, thiourea, an knew where given to subjects who did not know which one they were being asked to recognize. The different primate species are quite similar to thresholds obtained by directly reability, including recognition of the
Although embedded

in culture, humans'

acquisition of food

likes or dislikes is

comparable to

conditioned taste

responses in other

\section{mammals.}

havior because cognitive aspects associated with food profercees requir-

\section{SUGARS AND NONHUMAN} PRIMATES

Most nonhuman primates include fruits in their diet. The form and funcper a dive systems of severa pecies with the eer shaped in accord ing plants since the Mesozici? Although fruit composition varies across plant species and in relation to ripening, fruits generally include soluble forms of sugars, mainly fructose, glucose, and sucrose. The proportion of these sugars in fruits eaten by wild primates have been studied, especially Gri Lanka, Gabon, and French Gbility and interspecific differal avai-

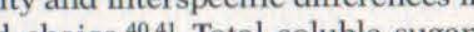
generally vary between $25 \%$ and $70 \%$

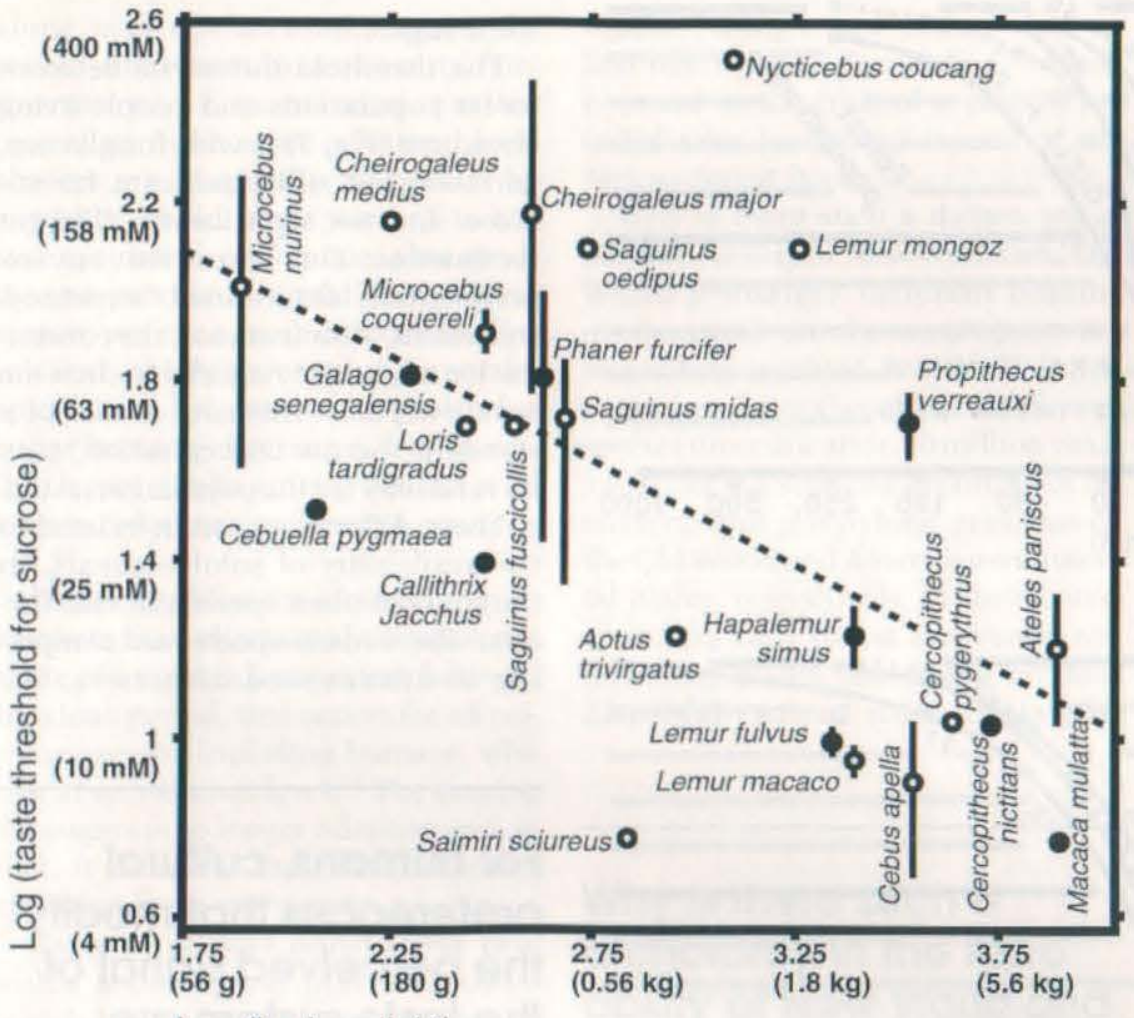

Figure 4. Correlation between the taste threshold for sucrose and the body weight of primate
species. Primates having a diet that includes large amounts of leaves or gums and less than $50 \%$ frut are shown by solid circles; open circles designate more frugivorous species. The function

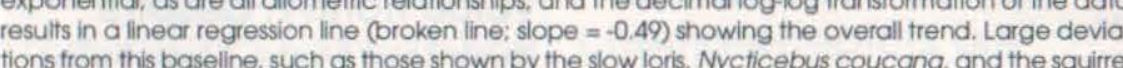

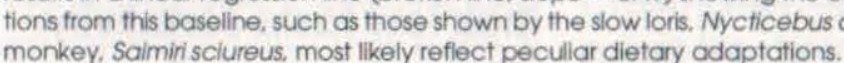

of the dry weight of ripe fleshy fruits (that is, about 60 to 180 grams per liter in the juice), although proportions low as $1.5 \%$ have been found in some wild fig species.

The thresholds for sucrose, which are known for 33 nonhuman primate species, ${ }^{42}$ vary between 6 and $330 \mathrm{mil}-$ limoles $(\mathrm{mM})$, which corresponds to 2 for fuctose, number of primates, appear to vary within similar limits across species. Because these "behavioral thresholds" are the minimum concentrations tha a fruit can have and still remain attractive to primates, ripe fruits have sugar content that can actually be tasted and that, for most primate species, produce a sensory reward. Surprisingly, the threshold for sucrose is correlated with species body mass (Fig. 4). We initially assume sponse to the composition of foods ships as reflecting the impor codies percive a wide range of Conties perceive a wide range of sugar with a relatively low sugar content, meet their energy requirements 46 The species shown in Figure 4 may tht often eat fruits (open circles) or may also include in their diet large are es) The lis between these categois a controus in daptive trends are revealed by shifts rom the regression line, although the wide scatter of data is partly due to naccuracy or differences between the methods used to measure thresholds. Among primate species differing noticeably from the common pattern (i.e., located outside of the regression can , he slow loris, Nycticebus coupresumably corresponding tocshold. alized decrease in taste sensitivity. This allows the use of pungent insects and other prey that are unpalatable to most primates. ${ }^{47}$ In contrast, the eclectic frugivorous diet of the squirmonkey, Saimiri sciureus, would necessitate a taste acuity better than . penditure of foraging in home ranges arge as 250 hectares. $^{48}$

In the method used for nonhuman primates, taste threshold is the limit above which a sensory reward can be However, the perceived intensity above threshold must obviously be of great significance in terms of sensory pleasure if it is to sustain a specific diet. For instance, the ingestive response of several tamarins increase tion than that of marmosets, even though these closely related species have similar taste thresholds.99,50 The difference corresponds to distinct dietary tendencies: tamarins feed mainly on sweet fruits, whereas marmosets, such as Cebuella pygmaea, most often eat tree exudates, especially gums that

\section{SUGARS AND HUMAN} POPULATIONS

Among the human populations investigated so far, taste thresholds fo sugars accord well with values predicted by the primate scaling model; body mass and anomnirorous feeding 

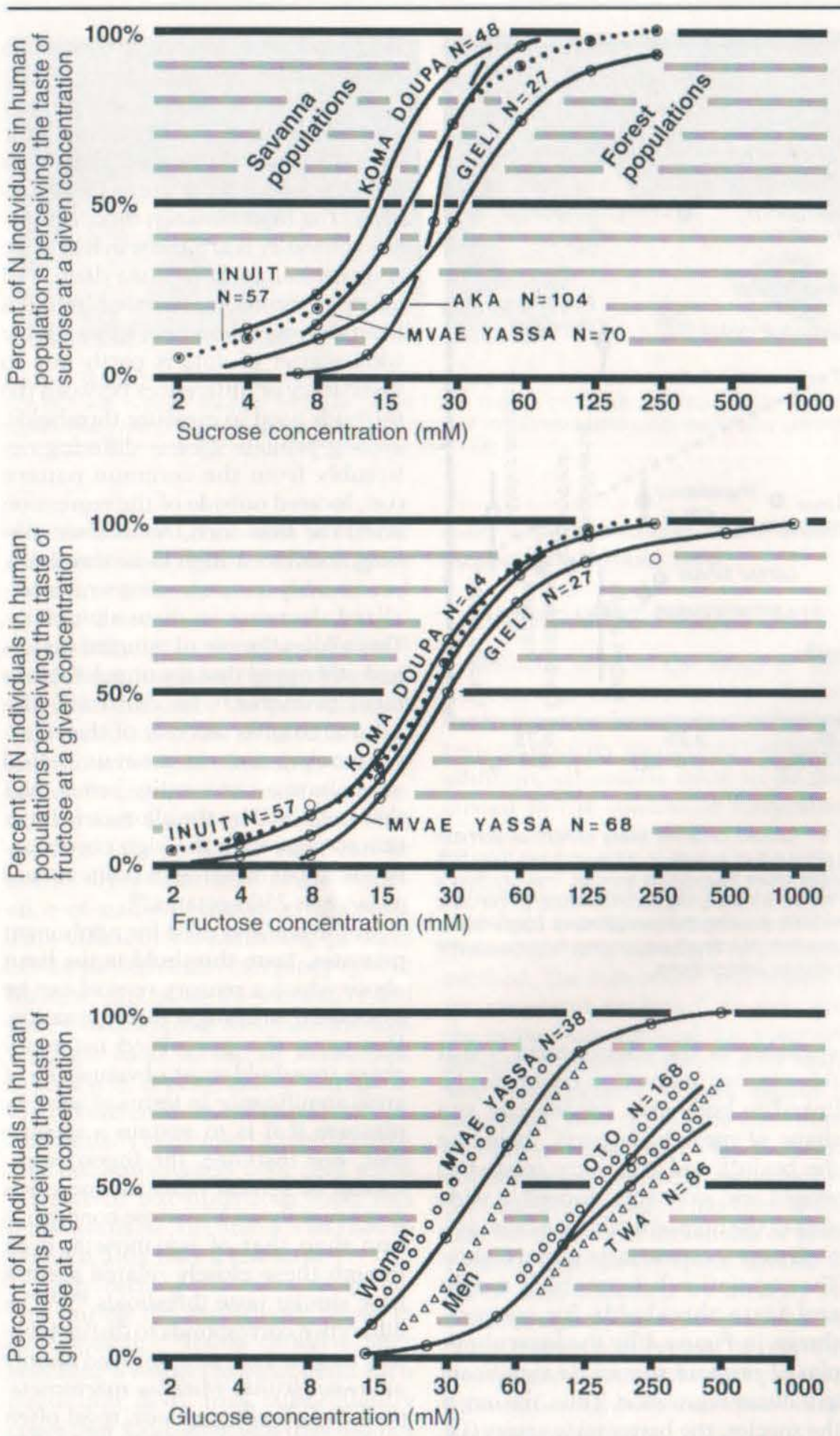

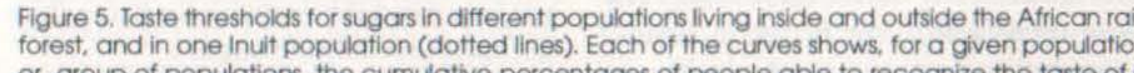

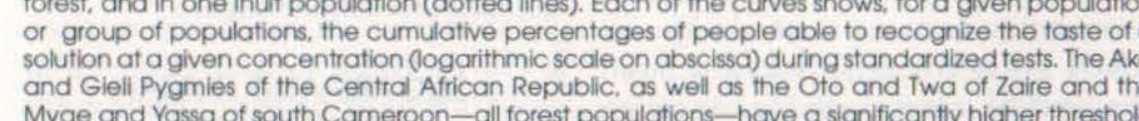

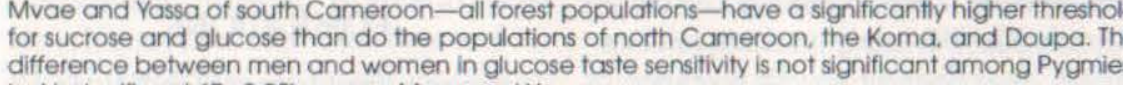
but is significant $(P<0.05)$ among Mvae and Yosso

strategy. Nevertheless, differences level in tropical rain forests and popuhave been observed between human lations living in other environments, populations living at a subsistence with respect to taste thresholds for some sugars. ${ }^{37}$

The threshold difference between forest populations and people living elsewhere (Fig. 5) is wide for glucose, crose, and not significantly different for fructose. This means that any experimentally determined "sweetnes equivalent," (for instance, the concensame sweetness intensity as that of a standard sucrose concentration) may be valid only for the population tested These differences can be related to the availability of soluble sugars, the fruits of plant species. In rain forests, where many species are compet-
ing to attract seed dispersers, the

For humans, cultural preferences that modify the perceived signal of the taste system are even more important. For instance, the Pygmies value honey, despite their low taste sensitivity for sugar because climbing a tree to collect honeycombs among furious wild bees is risky, making honey a precious gift.

sugar concentration in fruits can be high. Accordingly, it is not surprisin that Pygmies have a relatively poo cose at $200 \mathrm{mM}$ ) as compared with populations living outside the African tropical forest (median threshold at 50 $\mathrm{mM}$ ). Efficiency in finding energy i fruits can be increased by taste sensitivity in savanna populations facing a environmentin which low plant diversity results in fruits having lower suga content than do forest species.

Obrously, additional data would be needed to support this neo-Darwinian alone may not account for the observed differences in taste acuity. Furthermore, as mentioned earlier regarding nonhuman primates, food suprathreshold perception. For $h$ mans, cultural preferences that mod ify the perceived signal of the taste
system are even more important. Fo system are even more important. Fo inste their low laste sen honey, de sugar because climbing a tritity for lect honeycombs among furious wild bees is risky, making honey a preciou gift. ${ }^{52}$

In affluent Western societies, supermarkets have eliminated the season cycle of an abundant period followe by a lean period, that occurs for all prmate species, including humans, wh for sugars is fact, it increases the risk of diseases resulting from overweight.

Taste sensitivity nonetheless provides a biological platform upo which higher cognitive aspects act expand the perceived world. The fruits of the rain forest eaten by Pygmies have a sugar content 10 to 50 times solution perceived the weakest sug and appreciating their taste is still the field of biological phenomen Furthermore, several other interactions between sweet taste and the environment need examination.

\section{SWEET TASTE AND}

EVOLUTIONARY INTERACTIONS

Since saccharin was fortuitously was for products that taste extral nonsuger have been found, even among natura substances. Their chemical structure is totally different from that of sugars ${ }^{54}$; for instance, monellin, the nat ral sweet compound found in the red berries of a liana of the African rain forest, Dioscoreophyllum cumminsi, is a protein that as perceived by huthan sucrose at equivates sweeter centration. But monellin and other "natural sweeteners" are tasted mos keenly by Old World primates, including humans; New World primates are not able to perceive the taste of such sweet solutions. This difference in tasting ability is presently und tigation, using a new protein that we first described as "pentadin," 55 which is found in the fruit of a plant (Pentadiplandra brazzea

Why is there such a dichotomy in We taste ability of New World and $\mathrm{Ol}$ Wordes? most likely inoplors are in taste receptors would hav followed ecies diversification 30 million year ago, after the separate evolution of tarrhine and platyrrhine primates o tal plates, respectively. In their corresponding rain forest environments, flowering plants competing for seed

Why is there such a dichotomy in the taste ability of New World and Old World primates?

Different binding

mechanisms on

chemoreceptors are

most likely involved.

large amounts of sugars; the more sugar, the more efficient their dispertaste of "sweet proteins" at low concentration, the energy plants invest in their synthesis is low compared with that they invest in synthesizing suga As a result, genes coding for the fortutous emergence of proteins with tastes micking that of sugars would be secect cies: They work by the plant spewithout res although they do obtain a ensory re ward). As in Batesian mimicry such interaction is made possible by the idespread occurrence in rain forests of fruits with true sugars ${ }^{56}$ that serve This coevolution between primate and plants that contain nonsuga
Africa. In America, where no such substance has been found so far, one tionary process to have occurred. Jus as present African sweeteners are tosteless to American primates, sugar of American fruits might be cless the sweetent " 51 have yet to be red in the New World.

STARCHES, FATS, AMINO ACIDS, AND PROTEINS

Taste sampling of soluble sugars alows high energy intake through immediate preference, but this is not true Severl nutrition forie foodstuffs. ers, grains, nuts, ands, such as tuplant parts containing starch or fat, have little taste, even though they are staple foods for human populations. Similarly, gums and other plan exudates containing long-chain carbohydrates, which are consumed by several primate species and considered to be staple foods for lemur ancestors, are characterized by their peculia jelly-like texture, rather than by a typicate that tactiles cues (fat viscosity or the floury scratch of starch in the mouth) are important organolepti characteristics of these foodstuffs. ${ }^{38}$ The preference for fat has been primarily investigated among humans, or whom obesity and associated diseases are of major concern. The he donic value of oils, like that of sugars, lid versus the liquid forticty. The influences preferences 59 It is not clearly understood, in all instances, whether a proper taste signal helps to dentify starch and fat; the preference of newborn rats for starch ${ }^{60}$ could be based on either tactile cues or a typical aste response. Similarly, some pri- starchy substa various responses sibility of differential abilities to aste polymerized carbohydrates can As ruled out. ponses to soluble sugars, the apparntly imperfect taste response to these highly nutritious compounds could be elated to the fact that the radiation of 
flowering plants is relatively recent. the fifth taste, ${ }^{69}$ is particularly appre- not perceive the resulting salty taste Whereas sugars, always present in ciated by the Japanese. It is typical of (Fig. 6, top). However, the large petiplant metabolic pathways, may have crab hlesh, and may also contribute to oles of Musanga cecropioides, which angiosperms, fatty fruits seem to be the have already emphasized, there is no off and crunch, have a sodium chloresult of a more recentand sophisticated evidence that a limited number of ba- ride content reaching $1.34 \%$ of the dry evolutionary process. In this case, the sic tastes exists. We have to consider weight, ${ }^{70}$ a salt concentration that is trend toward reduction in the size of the each amino acid as separately eliciting above the threshold of some primate fruits is compensated for by their provision of greater energy intake: A fatty, thin aril provides more energy than does a sweet pulp. ${ }^{62}$ In consequence, the seed of such fruits is dispersed by a wid range of frugivorous animals.

Perception of substances with hig nutritional importance, such as amino zling. There is no simple relationshi between the role of essential aminoacids and their palatability. For instance, purified D-tryptophan is rejected by Cebidae and one lemur so far tested, but appears palatable to some Callithrichidae and Cercop thecidae. ${ }^{63}$ To humans, some amin acids or peptides taste sweet, whereas
others taste bitter. ${ }^{4}$ Protein that mimcs sugars falls in the category of subcs sugars talls in the category of subprimates according to the recency of their evolutionary radiations.

Primates meet their protein require ments by eating leaves, seeds, or anmal matter. The protein intake of leaf-eating primates, such as Presbytis spp., is above requirements, decreas ing slightly when fruits are mixed in large quantity with leaves. ${ }^{65}$ For such species, what is tasted may not be the choices: instead, the long-term postingestive effects common to all verto brates can efficiently regulate feeding behavior. In contrast, when capuchin monkeys or chimpanzees crack nuts to extract the seeds, an act necessitating high skill and energy expenditure, they may expect an immediate sensory reward. Whether starch, fat, and protein stored in seeds elicit specific taste perceptive factors, including Hever, and tactile cues, certainly contan to sensory pleasure. Chimpanzees sharing animal prey and slowly eating it in small pieces ${ }^{68}$ may combine taste pleasure with social contact.

"Umami," the taste of glutamic acid and derivatives (monosodium gluta- a singular "taste signature," genetically ut eventually modified socially acquired representations.

\section{SALT PERCEPTION}

The ability of vertebrates to taste se-

The extreme sensitivity to sodium observed in the Inuit population (median threshold at 8 $\mathrm{mM}$ ) can provide a selective advantage. The high Inuit sensitivity is associated with an aversion to too much salt, which traditionally is considered to be dangerous. have been considered as adaptive feaures that prevent sodium deficiency. ${ }^{30}$ especially in forest environments where available foods provide higher dietary supplies than estimated requirements. This was shown at Panama, Sri Lanka, and Gabon, wit sential minerals in the foods of various primate species. ${ }^{40,70}$

Although generally not lacking in the diet, sodium chloride is present at low concentration in most plant parts (less than $0.5 \%$ of the dry weight, or pelow $20 \mathrm{mM}$ concentration). Most ing between $5 \mathrm{mM}$ and $500 \mathrm{mM}^{63} \mathrm{can}-$ likely tor, mineral deficiencies are unrespect to sodium and some other es- species

Soil eating is common in primates, ${ }^{40,65,71}$ giving rise to the question of whether geophagy plays a role in mineral nutrition. Clay and other phyllitous soil materials that primates nins from the sto as adsont of tanmoleculesare retainedon the particles of clay). This beneficial effect is the most likely explanation for geophagy during periods of intense feeding on mature leaves that contain digestibility reducers such as tannins. ${ }^{72}$ Indeed, Johns and Duquette ${ }^{73}$ measured the amount of tannins bound with clay, demonstrating that adsorption is
efficient enough to allow quiet diges-

Like nonhuman primates, humans living in tropical forests are unlikely to ace sodium deficiency if they rely on relatively low sodium sensitivity of Pygmies," some populations of which (Fig. 6, top). Conversely, the extreme sensitivity to sodium observed in the Inuit population (median threshold at mM age. The high Inuit sensitivity is assoalt, which tratitionally is considered o be dangerous. ${ }^{74}$ As far in the past as 2000 BC, the Inuit population of the west coast of Greenland has concenrated all its food-gathering and hunting activities within a narrow coastal fringe. The staple that consistently has diet is seal meat and fat, presently dehispida) Seal water and without much sat The traditional life of hunter satherers, by now integrated into a modern socioconomic context, involves a diet having a particularly high protein As a result of the Inuit diet, drinking large amounts of water is physiologically necessary to prevent urea from plant foods. This might explain the provided most calories in the Inuit accumulating in the bloodstream. important feedback mechanism that is Early explorers of Greenland noticed necessary for the elimination of excess that all eskimo poptlations drank re- urea. A diet that includes a high water Draper 75 showed that this is an tionally high dietary-induced thepo-
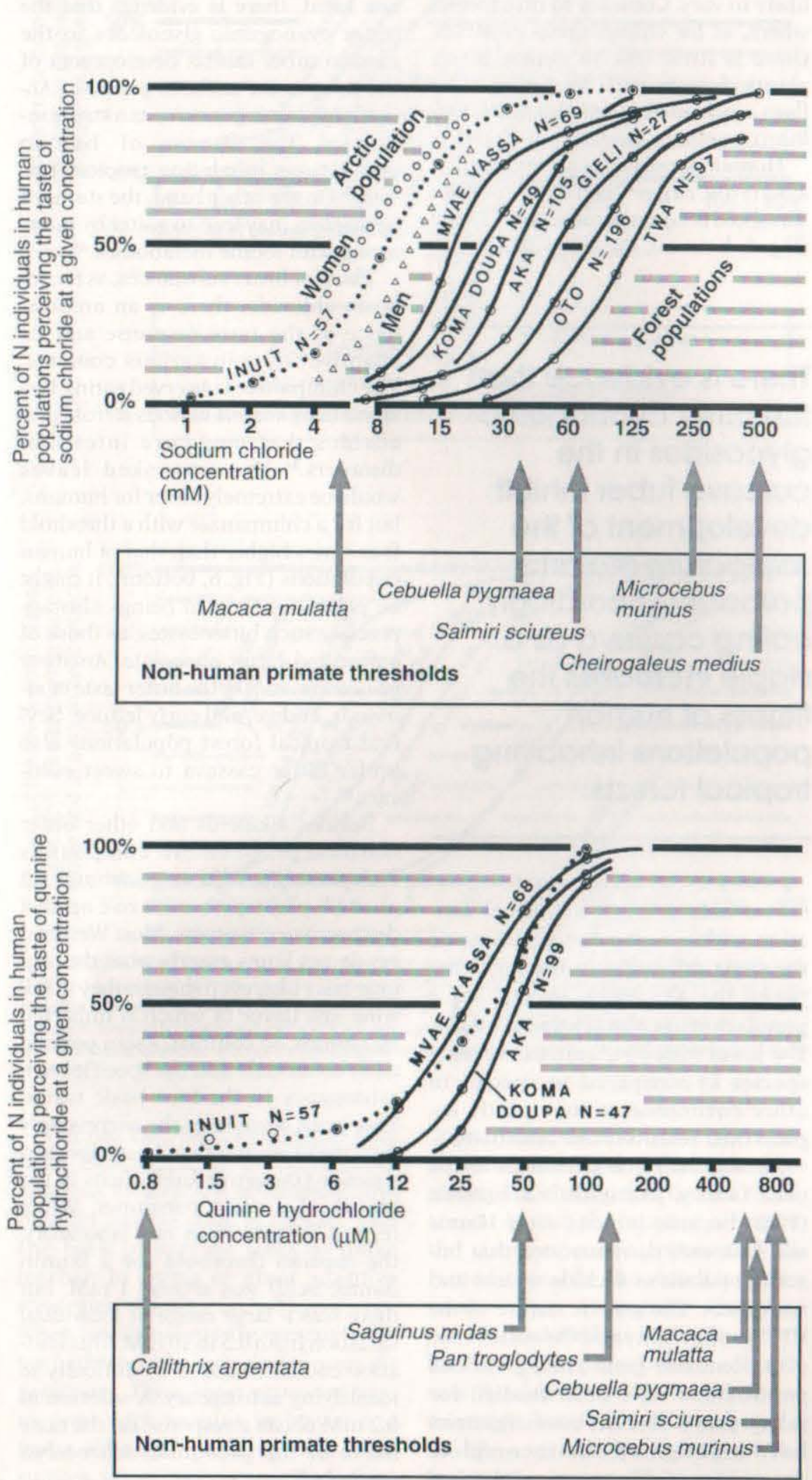

genesis (DIT); which leads to greater meat consumption to balance calorie rea results in con amounts of water The use of melted ce from small icebergs that have been in contact with salty water, which inreases the risk of sodium excess, needs accurate salt perception at low temperature. ${ }^{77}$ Although the risk of associated cardiovascular diseases mostly concerns adults, it is a selective pressure tavoring genes that code for vival traditionally depended on the hunting capacity of their fathers 43

\section{TASTE AVERSION AND FOOD} TOXICITY

Bitter plant substances such as several alkaloids, as well as astringent compounds (mostly tannins), terpenes, saponins, and strong acids

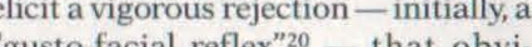
ously is adaptive, for many of these products are toxic. It is assumed that the ecological function of these potentially toxic substances is to defend the plant against harmful consumers. ${ }^{78}$ However, toxic species do not necessarily elicit a warning taste signal that such as the dioscine of Dioscorea his wild yam growing at the edge the African tropical forest is as dangerous as some Amanita spp. mushrooms growing in temperate forests. In most instances, however, a behavioral response, neophobia, ${ }^{79}$ prevents the ingestion of large quantities of a novel food, and thus minimizes the danger of plant toxicity. The ingestion heir food is sufficient to insampling

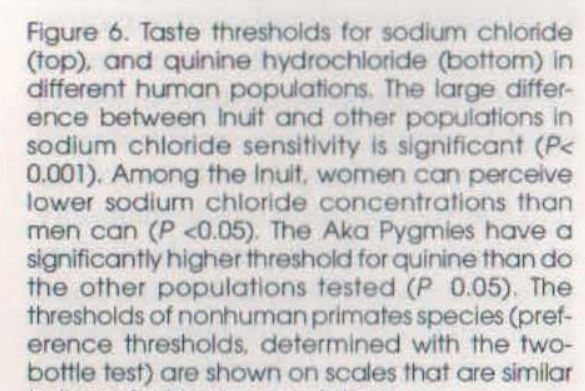


ingestive symptoms that lead to taste

aversion.
Glander'so
80 review of the effect of such substances on primate food choice shows that plant parts are fre quently selected on the basis of low ot a general rule; the concentratio and toxicity of these substances can vary widely in different types of envronments. In the Gabon rain fores or example, where $14 \%$ of the 382 plant specils tested rective cludes in its diet a similar proportion $(15 \%)$ of plants likely to have a high alkaloid content ${ }^{4}$ Accordingly, be cause chimps have no particular oxification system, most alkaloids in this environment can be compared to caffeine in their weak toxic effect. Furthermore, observation of chimpan-
zees in a montane forest "curing zees in a montane forest "curing themselves" with a bitter plant spe-
cies, Vemonia amygdalina, which usually is discarded by healthy he aversive revides evidence that be reversed. Whether this behavio qualifies as a medicinal practice base on cognition or whether it reflects conditioned taste response can be better understood in light of recent dat on primates perception of bitter substances One may wonder why taste thresh olds for quinine vary so widely from . bottom). In direct contrast to what was observed for sugars, no relationship could be found between the taste sensitivity to quinine and the body weight of different species. ${ }^{42}$ This should not surprise us; quinine is no a nutrient, the need for which would ncrease with body weight. A wide range in sensitivity may reflect the ac aptations of different primate species o different nutritional environments. Callithrix argentata, living on whiteand riverine forests, and Cebuel pygmaea inhabiting the interior of the rain forest. ${ }^{50}$ Both species feed mainly on the gum exuded by a tree bark after they have gouged it with their incisor These primates are in contact with bark substances evolved by tree species as chemical defenses (for stance, quinine is a chemical sub- that some others play a minor role. ${ }^{83}$ because of the differentents these marmosets live in, the alkaloid confronted with the noxious, bitter content and toxicity of the bark is substances of its environment? On likely to vary. Contrary to rain forests one hand, there is evidence that the where, as for chimpanzees in Africa, bitter cyanogenic glycosides in the there is little risk in eating bitter cassava tuber inhibit development of plants, forests with less diversified the falciparum malaria parasite. Aclora, such as that inhabited by Cal- cordingly, eating cassava as a staple inHuman populations are grouped in creases the fitness of human narrow range having a median populations inhabiting tropical forthreshold for quinine of around $25 \mu \mathrm{M}$ csus Fig. 6, bottom); the steep slope of all fering with iodine metabolism 85 Thus forbitter substances, as for sodium chloride, there is an ambiva ence of the taste response and its

There is evidence that the bitter cyanogenic glycosides in the cassava tuber inhibit development of the falciparum malaria parasite. Accordingly eating cassava as a staple increases the fitness of human populations inhabiting tropical forests.

curves indicates low individual varithen within a population. However ween the Aka Pygmies and other populations is significant $(P<0.05)$. The lower toxicity of rain forest plant pecies as compared to species in plain their relatively low sensitivity Among the bitter chemicals in the urea family, phenylthiocarbamide (PTC) became famous after Harris and Kalmus ${ }^{82}$ demonstrated that human populations include tasters and nontasters. The genetic nature of the PTC tasting ability and the occurrence of a dominant gene among various populations have been studied for many years. Recent investigation have highlighted the incomplete
dominance of one gene and the fact adaptive value in various contexts. The chimpanzees observed eating Vernonia leaves ingest various steroid glucosides that may cure intestinal disorders. ${ }^{86}$ The uncooked leaves would be extremely bitter for humans, four times higher th tha threshold four times higher than that of human be palatable. Human beings also appreciate such bitter tastes, as those of coffee and bitter chocolate. Amateur gastronomers like the bitter taste of almonds, endive, and curly lettuce. Several tropical forest populations also prefer bitter cassava to sweet culti-

Besides alkaloids and other bitter substances, phenolic compounds pon destructive consumers. Most Westerners do not know exactly what the tanins taste like, even though they drink wine, the flavor of which is imparted by tannins. In contrast, Asian populations commonly add the specific term astringency to the four basic tastes. This word designates the surprisingly distasteful feeling that an unripe permouth (Diospyos kaki) elicits in the esting volunters in he median threshold for a tannin. (tannic acid) was around $1 \mathrm{mM}$, but there was a large range of individual ariation from 0.3 to $10 \mathrm{mM}$. This variation could be caused by difficulty in dentifying astringency. A solution at $0.2 \mathrm{mM}$ elicits a response on the taste nerve of the prosimian Microcebus murinus. ${ }^{89}$
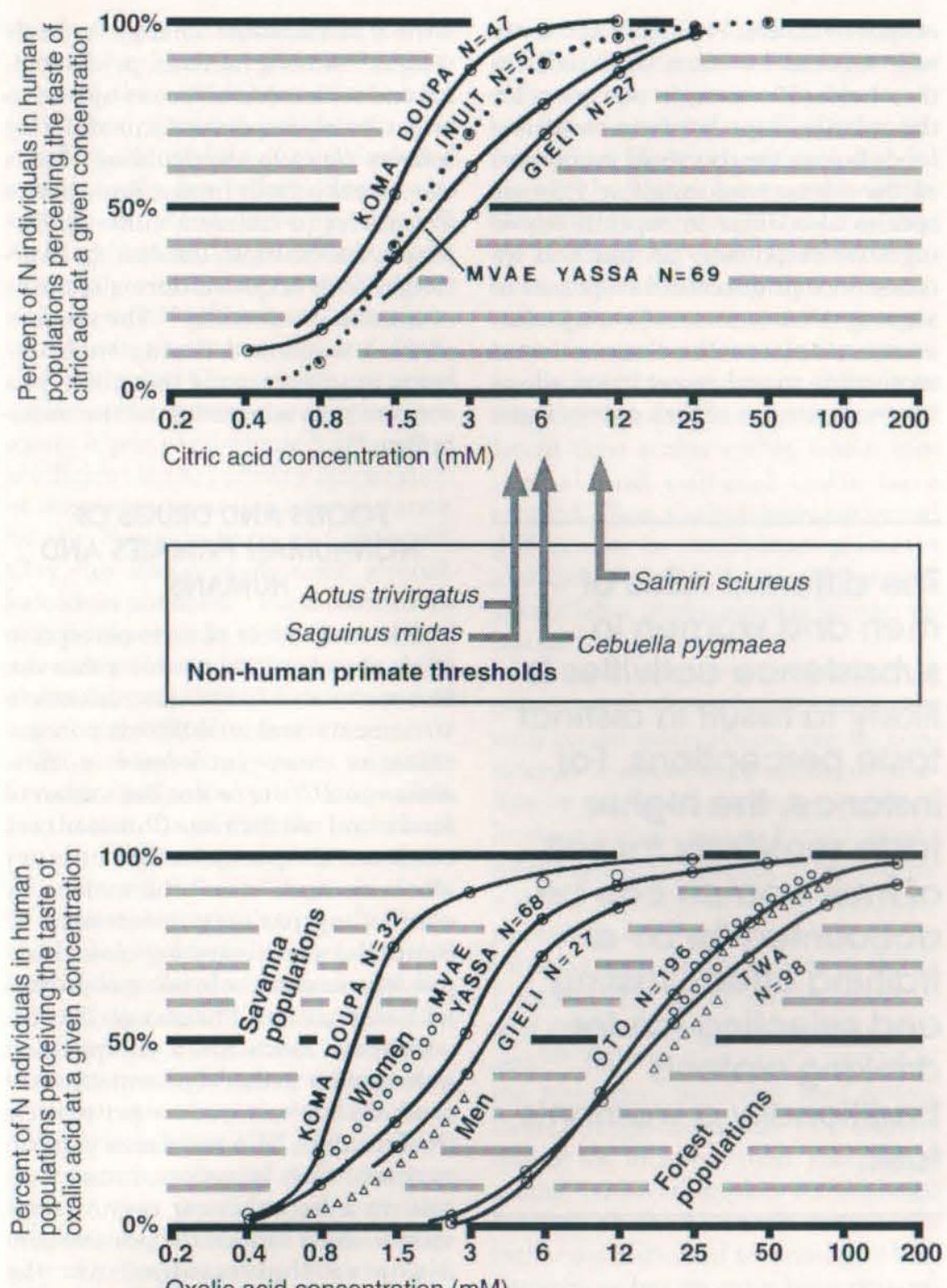

Figure 7. Taste thresholds for citic acid (top) and oxall c ccld (bottom) in different human populawhereas preference thresholds (two-bottle fest) are shown for nonhumanan primates. Differences ? $(P 0.05)$

Tannins can bind strongly to pro- densed tannins and hence their unteins. Even in ancient times this prop- pleasant taste, tend to decline as fruit erty was well-known to tanners, who matures, a change that occurs simulbrought animal skins in contact with taneously with the increase of sugars the bark of various trees to make the taste response is necessarily dileather. In terms of plant adaptive rected towards the resulting mixstrategies, tannins are efficient only tures. For instance, Callithrix when large amounts are present to de- jacchus and Callimico goeldii, which ter herbivores by reducing protein di- have similar perceptions of frucgestibility. Thus, most primates have tose, ${ }^{, 0}$ tolerate tannin and fructose to cope with tannins in leaves and mixtures, but reject them when the fruits, although tolerance to these sub- tannin content reaches $4 \%$ of the for sugar in the mixture, the more tannin is tolerated.

\section{ADAPTATION TO ACIDS}

A strong acid taste is generally deterrent. The mild reaction of babies to an acid taste, a gusto-facial reflex con(sting of hp-pursing, obviously is a acid used in this test. Strong acids elicit a painful trigeminal response 99 Chili and hot pepper cause this response to merge with all other parameters of the taste signal. Owing to the risk of excessive variation of the $\mathrm{pH}$ of the milieu interne, as for instance, when a lemon or lime $(\mathrm{pH}$ as low as 2 is ingested, the adaptive naextreme sourness can be inferred. Taste thresholds for citric acid among the nonhuman primates so far tested do not differ widely from those of human populations whose median thresholds (Fig. 7, top) lie between 1.5 and $4 \mathrm{mM}$. Oxalic acid present in several plant species (such as the leaves of sorrel, Rumex acetosa) elicits ex(remen dian threshold ranging from 1 to 20 $\mathrm{mM}$.

One primate species, the night nonkey (Aotus trivirgatus), which includes sour fruits in its diet, shows a preference for citric acid solutions at ow concentration, whereas all other primates tested avoid sour solutions. ${ }^{92}$ A more subtle difference has been ob(recies ruits eaten by gibbons (Hylobotes lar) re extremely acid, having a $\mathrm{pH}$ s low as 1.5 , orangutans (Pongo pygmaeus) and macaques (Macaca fascicularis) eat larger proportion of fruits with a $\mathrm{pH}$ between 4 and 5 . Langurs (Presytis thomasi), which eat more fruits with a pH >5, avoid the most acidic 政 anism tha allow fercic he forestomach, which is a characteristic of all leaf-monkeys. A decrease in acid content accomccumulation in ripengruits. Because the sourness of a 政 s palatability, making the pulp as at - 
tractive to wild primates as soft drinks are to children. The pleasantness of a mildly sour taste may help meet re-
quirements for ascorbic acid (vitaquirements for ascorbic acid (vita-
min C). However, considering the ascorbic acid content of leaves an mates do not risk being deficient.

\section{FEEDING STRATEGIES AND TASTE} PERCEPTION

Primate diets can be understood in terms of feeding strategies, the various ways used tocope with potential foods Whereas some species tend to supple ment a diet of animal matter with fruits, others are mainly frugivorous. Still others use leafy materials as a ma jor energy source. These materials have very different nutrient contents, ${ }^{, 6}$ especially in terms of sugars. The preference for soluble sugars which is observed in all primates, allows an efficient quest for foods havstrategies can be maintained throu differently perceived intensities taste stimuli. For instance, macaques and capuchins need to spend grea amounts of energy to find scattered re sources such as sweet fruits and in
sects; in turn, these resources provide sects; in turn, these resources provid a high energy return. Conversely, spe cies such as langurs and howlers eat mo cocies, which give energy necessitates a lower energy invest ment than required of macaques an capuchins. To account for these opposite strategies, which imply a grade of intermediate types, a model in whic taste perception plays a major role ha been proposed. According to this model, species with the highest tas nutrients tend to improve foraging ficiency, whereas species with taste responsiveness mostly rely on the long-term satiating effect of low calorie foods.

Taste sensitivity for sugars tends to increase with a species body mass, illustrated in Figure 4. Furthermore, most species that depart from this paries, energy ing toward cither the high tasters, or the low energy input an output of others. Phylogenetic inertia may account for some similitudes in of species also differ in suprathreshold also varies in different cultures. The ingestive responses ${ }^{50} \mathrm{~A}$ marked in Massa for example, idealize the overcrease in suprathreshold responses to weight body acquired during session sugar concentrations, reflecting a fast of intense overfeeding 98 The amoun increase in pleasantmess, mayenhance of food consumed during such sesmotivation to seek sweet fruits, allow- sions is so enormous that there is a ing for strategies of high energy input concomitant adaptation of the meta-

FOODS AND DRUGS OF HUMANS

The different roles of men and women in

subsistence activities is likely to result in distinct taste perceptions. For instance, the higher taste sensitivity for salt of Inuit women can be accounted for by a training effect: tasting and selecting ice for drinking water is traditionally a woman's task.

and output even among small specie Although median taste threshold in human populations fit the model, they obviously are not sufficient to account for most differences in food choices without also addressing the extremely diversified cultural considexs associated with obesity are a major concern in the prehats a western world, where food seasol arior determined by period For wild including a lean ins living a subsistes and populaperis coping with uncertinty in food sup9y ${ }^{97}$ In the lesser mouselemur Microcebus murinus, as well as in other Cheirolidae, there is a seasonal varation in sugar preference concomitan
Early hominids evolved in a chang(n) which nutrients tial foods. An extrapolation from the present food habits of hunter-gatherers and the rare information about
fossil food plants in prehistoric sites fossil food plants in prehistoric sites animal foods, but in large degree was based on plant carbohydrates. Among these resources, acorns nece only to improve their taste, but to prevent binding with protein, and digestive difficulty. Clay, which, as note earlier, chimpanzees and other prmates ingest to eliminate leaf tannin of acorns and was used, for instance, by the Pomo Indians of Califoria. Clay can also detoxify toxic alycoalkaloids in potatoes. ${ }^{73}$ Food technology may have been one of the first cultura advances of hominids, though some chemical properties of plants would have been difficult to overcome

Physiological responses to toxin are extremely diverse. 104 They allow for several plant species that poisonous if eten in lare amouns. In natural environments, alcohol isexclusively present in sweet fruits th have fallen on the ground and fermented. Goodall, ${ }^{106}$ quoting Temerlin describes a chimpanzee "laughing. and getting high" after eating conpletely rotten fruits. Most huma populations generally use alcoholi texts. $^{2}$ Other products us in contexts might be more noxious if in gested in large quantity. For example the Inuit enjoy consuming smal pieces of shark meat that have bee left in fresh water for six days, which thus have developed a strong odor of ammonia and are likely to contai

TASTING ABILITY IN HUMANS

In some human populations, we found a significant difference between the taste thresholds of men and dium chloride (Fig. 6, top) and oxali acid (Fig. 7, bottom). Corresponding sex d. non-human primates have not ye and Teleki ${ }^{107}$ suggested that differences in the feeding behavior of male and female pongids may have consti- tuted the first evolutionary step toward a hominid division of labor. The hastes of men and women in distince taste peris likely toresult ance, the higher taste sensitivity for con or by a training effect: tasting and seecting ice for drinking water is tradian's task. A genetic basis for such differences cannot be Hladik108 at present; however a logical and cultural traits have evolved. Thus, the link between sexual differences in nonhuman primate and the cultural determinants of divicieties is only tenuous.

In evolutionary terms, the retention f ancestral characteristics, together with recent adaptations, can be contitute a common baseline in the feeding trends of various human populations. Fruits might a been the staple for hominids for pected time than was previously susa Foot," a species of Australopithecus ago. ${ }_{109}$ Jolly 110 presented a model of the transition, involving seed eating from a frugivorous diet to a starchy diet of the incipient man. Feeding on grains, however, implies the seasonal storing of food, which requires a ther sophisticated technology. Altertivedy hers, ain forests throughout the year, could have marked the beginning of starchy aple use. III The mild taste of starchy foods can explain the long-lasting practice of enhancing their palatability by adding other ingredients. Cooking, a further step in taste the substances like tion between by the Maillard's reacon a roasting piece of meat.

A great number of taste carriers, inharmful in large that normally are multaneously involved in any beting experience. Like bitter substances in beer, a bit of astringency, together with several aromatic volatiles, makes goo wines. But, just with palm wine used hroughout the tropical world, ${ }^{112} \mathrm{sym}$ bomicioecomic beyond the convergence of taste olfactory stimuli, and trigeminal information in the mammalian brainstem and beyond the psychosensory responses common to nonhuman pri-

\section{ACKNOWLEDGMENTS}

We thank R.A.A. Oldeman (Wageningen University), who read the first com of this paper and provided accosyntrome," John G. Fleagle an Kelly McNeese for their editorial conributions, and particularly Olga F. Linstitute), who clarified our text to make it palatable. REFERENCES

Robbe P (1994) Les Inuit d'Ammassalik,
Chasseurs de 'Arctique. Paris: Editions du
Muséum National d'Histoire Naturelle, 2 de Garine I (1993) Food resources and pref-
erences in the Cameroonian forest. In Hladik
CM. Hladik A. Linares OF Pagezy H, Semple
A Hadley M (eds) Tropical Forests. Peopleand Food: Biocultural Interactions and Applica.
tions to Development, 0 . $561-574$. Paris: 3 Jolly A (1972) The Evolution of Primate Be Hladik CM (1981) Diet and the evolution of eeding strategies among forest primates. In
Harding RSO, Teleki G (eds), Omnivorous Prinates. Gathering and Hunting in Human Evo-
lution, pp 215-254. New York: Columbia
University Press. 5 Whiten A, Widdowson E (eds) (1992) Forag.
ing Strategeies and Natural Diets of Monkeys,
Apes and Humans. Oxford: Oxford University 6 Van Buskirk RL, Erickson RP (1977) NTS. Brain Res 135:287-303.
NTS

7) Stillman JA (1993) Color influences flavor
identification in fruit-flavored beverages. J Food Sci $58: 810-812$

8 Rolls ET (1995) Central taste anatomy and
neurophysiology. In Doty RL (ed) Handbook of Olfaction and Gustation, pp 549-573. New 9 Schiffman SS, Erickson RP (1980) The issue ci Biobehav R 4:109-1 10 Faurion A (1987) Physiology of the sweet
taste. In Otosson D (edd, Progress in Sensory Pher-Verlag. pp. 130-201. Heidelberg: Sprin11 Faurion A (1988) Naissance et obsoles.
cence du concept de quatre qualitits en gusta12 Faurion A (1993) Why four semantic taste
descriptors and why only four? 11 th Interna-
tional Conference on the Physiology of Food 
13 Le Magnen J (1995) Gustation. In Encyclo-
pedia Universalis 11, pp 83-87. Paris: Encyclopedia Universalis.
14 Nowlis GH, Frank ME (1977) Qualities in In Le Magnen I, Mac Leod P (eds), Olfaction
and Taste VI, pp 241-248. London: IRL. 15 Hofer OF, Meinel W. Sauer E (1990) Ver-
gleichend-anatomische Untersuchungen an den Zungen von Pantroglodytes (Blumenbach,
1799 ) und weiteren Primates. Gegenbaurs
Mornhol Jahrb 136:455-492. 16 Hellekant G, Ninomiya Y (1994) Bitter taste in single chorda tympani taste fiber
from chimpanzee. Physiol Behav 56:1185 1188.
17 Tonosaki K, Funakoshi M (1984) Intracel-
lular taste cell responses of mouse Comp Biochem Physiol A 78:651-656

18 Erickson RP, Covey E (1980) On the sing
larity of taste sensations. Physiol Beha 25:527-533. 19 Steiner JE (1977) Facial expressions of the food-related chemical stimuli. In Weiffenbac JM (ed), Tasteand Development: The Genesis of
Sweet Preference, pp $173-189$. Bethesda: U.S
Department of Health, Education and Wel. 20 Steiner JE, Glaser D (1984) Differential be 20 Steiner JE, Glaser D (1984) Differential be-
havioral responses to taste stimuli in nonhuman primates. J Hum Evol 13:709-723.
21 Chiva M (1985) Le Doux et l'Amer. Paris. 22 Pfaffmann C (1960) The pleasures of sen-
sation. Psychol Rev 67:253-268. 23 Fantino M, Hosotte J, Apfelbaum M (1986) Areference for sucrose in humans. Am
prysiol 25l-R91 24 Rolls BJ, Rolls ET, Rowe EA, Sweeney K
(1981) Sensory specific satiety in man. Physiol 25 Rolls ET, Sienkiewicz ZJ, Yaxley S (1989) Hunger modulates the responses to gustatory
stimuli of single neurons in the caudolatera stimuli of single neurons in the caudolateral
orbitofrontal cortex of the macaque monkey. 26 Cabanac M, Fantino M (1977) Origin tivity to carbohydrate concentration? Physio 27 Rabe E, Cabanac M (1974) Origine de Pal. d'une huile végétale et du glucose intragastr. 28 Louis-Sylvestre J, Le Magnen J (1980) A A al in blood glucose level precedes meal onset in
free-feeding rats. Neurosci Biobehav $\mathrm{R}$
4 29 Bellisle F, Lucas F, Amrani R, Le Magnen
(1984) Deprivation, palatabilitity and the mi-
cro-structure of meals in human subjects. petite 5:85-94.
30 Le Magnen J (1985) Hunger. Cambridge 31 Rolls BJ, Rolls ET (1982) Thirst. Cam-
bridge: Cambridge University Press. 32 Garcia J, Koelling RA (1966) Relation of a

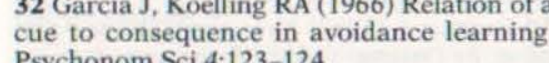
33 Brand JG, Kare MR, Naim M (1980) Re among taste, acceptability, and digestion. In
Pearson PB, Greenwell JR (eds), Nutrition, Pearson $\mathrm{PB}$, Greenwell $\mathrm{JR}($ eds), Nutrition
Food and Man. An Interdisciplinary Perspec
tive, pp 105-123. Tucson: The University o

34 Rozin P (1990) Acquisition of stable food
preferences. Nutr Rev 48:106-113.

35 Simmen B, Hladik CM (1988) Seasonal
variation of taste threshold for sucrose in a prosimian species, Microcebus murinus. Folia
Primatol $57: 152-157$. 36 Glaser D, Hellekant G (1977) Verhalten
und electrophysiologische Experimente über den Geschmackssinn bei Saguinus midas 28:43-51. 37 Hladik CM, Robbe B, Pagezy H (1986) SenPygmées et non Pygmées de forét dense, de . III 303:453-458.

Aspects méthodologigues de len des saveurs Aspects méthodologiques de lacquisition et
de linterprétation des donnnés. In Froment A
de Garine t, Binam Bikoó C, Loung JF (eds) Bien Manger et Bien Vivre. Anthropologie A A
mentaire et Developpement en Afrique Inter. ropicale:Du Biologique au Social, pp 99-108. 39 Hladik CM, Chivers DJ (1994) Foods and
the digestive system. In Chivers DJ, Langer P eds), The Digestive System in Mammals: Food
Form and Function, pp 65-73. Cambridg Cambridge University Press. 40 Hladik CM (1977) Le régime alimentaire
des primates et son adaptation aux ressources du milieu forestier. Thèse Doctorat d'Etat
Université Paris VI and Museum National 41 Simmen B, Sabatier D (n.d.) Diets of some French Guianan primates: Food compositio
and food choices. Int J Primatol, in press 42 Simmen B, Hladik CM (n.d). Sweet and bitter taste discrimination in primates: Scallia Primatol, in press
43 Simmen B. Hladik CM (1993) Perceptio tritionnel des primates non-humains et des populations humaines. Bull Mém Soc Anthro44 Martin RD (1981) Relative brain size and
basal metabolic rate in terrestrial vertebrates. basal metabolic rate in terrestrial vertebrate.
Nature 293:57-60. 45 Martin RD, Chivers DJ, Maclarnon AM,
Hladik CM (1985) Gastrointestinal allometry in primates and other mammals. In Jungers
WL (ed), Size and Scaling in Primate Biology, pp 61-89. New York: Plenum.
46 Simmen B, Hladik CM, Martin RD (1995) 46 Simmen B, Hladik CM, Martin RD (1995)
Sweet and bitter taste discrimination and en-
ergy requirements in nonhuman primates.
Chem Senses 201153 47 Hladik CM (1979) Diet and ecology of
Prosimians. In DovleGA, Martin RD (eds). Th Study of Prosimian Behavior, pp 307-357. New
York: Academic Press. 48 Terborgh J (1983) Five New World Pri-
mates. A Study in Comparative Ecology 49 Simmen B (1992) Seuil de discrimination et réponses supraliminaires à des solutions de rructose en fonction du régime alimentaire
des primates Callitrichidae. CR Acad Sci Paris III 315:151-157. mates. In Chivers DJ, Langer P (eds). The Digestive System in Mammals: Food, Form and
Function, pp 150-165. Cambridge: Cambridge 51 Hladik CM (1993) Fruits of the rain fores interactions. In Hladik CM, Hladik A. Linares OF, Pagezy H, Semple A, Hadley M (eds)
Tropical Forests, People and Food: Biocultural

p 73-82. Paris: UNESCO-Parthenon Publish2 Hladik CM, Bahuchet S (1994) Perception y the Aka Pygmies (Central African Repub-
. In Thierry B, Anderson JR, Roeder JJ. Terrenschmidt N (eds). Current Primatology.
lol. I, Ecology and Evolution. Selected Proceedings of the XIVth Congress of the Inter53 Hladik CM (1988) Seasonal variations in Harrison GA (eds), Coping with Uncertainty in
Hod 54 Van der Wel H, van der Heijden A, Peer HG 1987) Sweeteners. Food Rev Int 3:193-268. CM, Hellekant G, Glaser D (1989) Isolation and characterization of pentadin, the sweet
principle of Pentadiplandra brazzeana Baillon. 56 HladikcC, Hladik A (1988) Sucreset ufaux sucress de la forêt équatoriale : Évolution et
perception des produits sucrés par lesp popu-
lations forestieres d'Afrique. J Agr Trad Bot 57 Nash LT (1986) Dietary, behavioral, and
morphological aspects of gummivory in prinates. Yearb Phys Anthropol 29:113-137. 58 Mela DJ, Langley KR, Martin A (1994) Sen-
sory assessment of fat content Effect of emul-
sion and subject characteristics.Appetite 59 Drewnowski A, Shrager EE, Lipsky C, Stel-
lar E, Greenwood MRC (1989) Sugar and fat: Sensory and hedonic evaluation of liquid and
solid foods. Physiol Behav $45: 177-183$. 60 Perez C, Sclafani A (1990) Developmental
hanges in sugar and starch preferences in Sclafani A (1988) Taste prefrences of squirrel monkeys and bonnet macaques for polycose, maltose and sucrose. 62 McKey D, Linares OF, Clement CR, Hladik orests in relation to food availability Back.

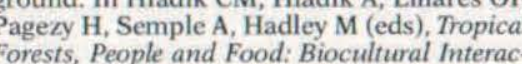
tions and Applications so Development, pp 17-
24. Paris: UNESCO-Parthenon Publishing 33 Glaser D (1986) Geschmacksforschung be 10 . 64 Haefeli RJ, Glaser D (1990) Taste responses mino acids in humans. Lebensm Wiss
fechnol $23.523-527$. 65 Hladik CM (1977) A comparative study of of leaf monkeys: Presbytis sener and Presbytis Ecolog. St Cludies of Feeding and (ed), Primate haviour in Lemurs, Monkeys and Apes, pp 323 66 Izawa K, Mizuno A (1977) Palm-fruit chin (Cebus apella). . Himates $18.775-792$. 67 Boesch C, Boesch H (1981) Sex differences
in the use of natural hammers by wild chim-
panzees: A preliminary report. J Hum Evol
10.585 .93 68 Teleki G (1973) The Predatory Behavior of versity Press.
69 Kawamura Y, Kare MR (eds)(1987) Umami
A Basic Taste. New York: Marcel Dekker.
70 Hladik CM (1977) Chimpanzees of Gabon
and chimpanzees of Gombe: Some comparative data on the diet. In Clutton-Brock TH (ed) Primate Ecology:Studies of Feeding and Rang-
ing Behaviour in Lemurs, Monkeys and Apes,
p $481-501$ London: Academic Press. 71 Oates JF (1978) Water-plant and soil consumption by guereza monkeys (Colobus
guereza): A relationshipa with mineralsand tox
ins in the diet ? Biotropica $10: 241-253$. ins in the diet ? Biotropica 10:241-253.
72 Hladik CM, Gueguen L (1974) Géophagic et nutrition minerale chez les primates sau-
vages CR Acad Sci Paris III 279:1393-1396. vages. CR Acad Sci Paris III 279:1393-1396.
73 Johns T, Duquette M (1991) Detoxification 73 Johns T, Duquette M (1991) Detoxification
and mineral supplementation as functions of
gecphasy geophagy. Am J Clin Nutr 53:448-456. sponses, food choices and salt perception
among the Inuit of Greenland. In Thierry $B$
Anderson $J R$, Roeder J, Herrenschmidt $N$ Anderson JR, Roeder Jo, Herrenschmida
(eds). Current Primatolog. Vol. I, Ecology and
Evolution. Selected proceedings of the XIVth Congress of the International Primatological
Society, pp 151-154. Strasbourg: Universite 75 Lois Pasteur. (1977) The aboriginal Eskimo diet in modern perspective. Am Anthropo
$79: 309-316$.
76 Speth JD (1987) Farly hominid subsistence 76 Speth JD (1987) Early hominid subsistence
strategies in seasonal habitats. J Archaeol Sci
14:13-29.

77 Pangborn RM, Chrisp RB, Bertolero LM sponses to solution of sodium chloride at four temperatures. Percept Psychol 8:69-75.
78 Whittaker RH, Feeny PP (1971) Allelo78 Whittaker RH, Feeny PP (1971) Allelo-
chemics: Chemical interactions between species. Science 171:757196770.
79 Rozin P (1976) The selection of food by J. Hinde RA, Beer C, Shaw E (eds), Advances
in the Study of Behavior, Vol. 6, pp 21-76. New York: Academic Press,
Yol. 6, pp 21-76. New 80 Glander KE (1982) The impact of plant sec.
ondary compounds on primate feeding behavondary compouinds on primate feeding
ior Yearbk Phys Anthropol 25:1-18.

81 Huffman MA, Seifu M (1989) Observation
on the illness and consumption of a possibly. on the illness and consumption of a possibl.
medicinal plant, Vermonia amydalatina (Del.). by a wild chimpanzee in the Mahale Moun-
tains National Park, Tanzania. Primates

82 Harris H, Kalmus $\mathrm{H}$ (1949) The measure
ment of taste sensitivity to phenylthioure

83 Reddy BM, Rao DC (1989) Phenylthiocar-

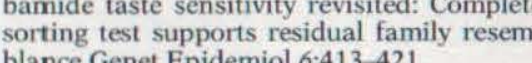
84 Jackson FLC (1993) The influence of die-
tary cyanogenic glycosides from cassava on tary cyanogenic glycosides from cassava
human metabolic biology and microevolu
tion. In Hladik CM, Hladik A, Linares $O$ Pagezy H, Semple A, Hadley M (eds), Tropica
Forests, People and Food: Biocultural llotere

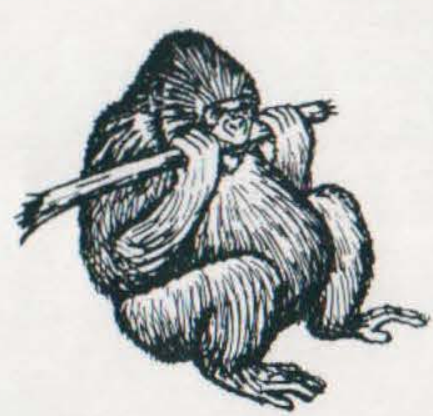

1ions and Applicationsto Development, pp $321-$
338. Paris: UNESCO-Parthenon Publishing 85 Boyce AJ, Harrison GA, Platt CM PTC taster status and goitre in a Papua New 86 Koshimizu K, Ohigashi H, Huffman MA,

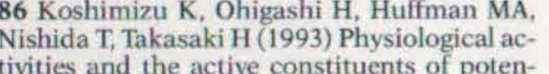
ially medicinal plants used by wild
himpanzees of the Mahale Mountains, Tan7ania.Int J Primatol 14:345-356.
87 Dufour DL (1993) The bitter is sweet: A 87 Dufour DL (1993) The bitter is sweet: A
case study of bitter cassava (Manihot escut
lenta) used in Amazonia. In Hladik CM, Hladik (enta) used in Amazonia. In Hladik CM, Hladik Biocultural Interactions and Applications to Parthenon Publishing Group.
88 Swain T (1979) Tannins and lignins. In 88 Swain T (1979) Tannins and lignins. In
Rosenthal GA, Janzen DH (des). Herbivores. heir interaction with Secondary
tes, pp 657-68nt 89 Hellekant G, Hladik CM, Dennys V, Sim-
men B, Roberts TW, Glaser D, DuBois G, WalMalagasy primates (Microcebus m murrinus and Eulemur mongoz). Chem Senses 18:307-320. 90 Ganzhorn JU (1989) Primate species sepa-
ration in relation to secondary plant chemi91 Bryant BP, Moore PA, O'Bannon Y (1994) Oral trigeminal chemoreception of acidiciriti-
tants: Role of the epitheliumm, neural coding and behavioral correlates. Proceedings of the 92 Glaser $\mathrm{D}$, Hobi $\mathrm{G}$ (1985) Taste responses in
primates to citric and acetic acid. Int J Prima93 Ungar PS (1995) Fruit preferences of four sympatric primate species at Ketambe, North64:221-245. sory integration in citriclacid sucrose mix 1987) Ascorbic acid wild monkeys and bats. Experientia 43:339-

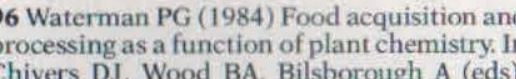
Food Acquisition and Processing by Primates. 97 de Garine I, Harrison GA (eds.) (1988). Cop$8 \mathrm{de}$ Garine I (1980) Approaches to the study
If food and prestige in savanna tribes, Mass nd Mussey of Northern Cameroon and Chac

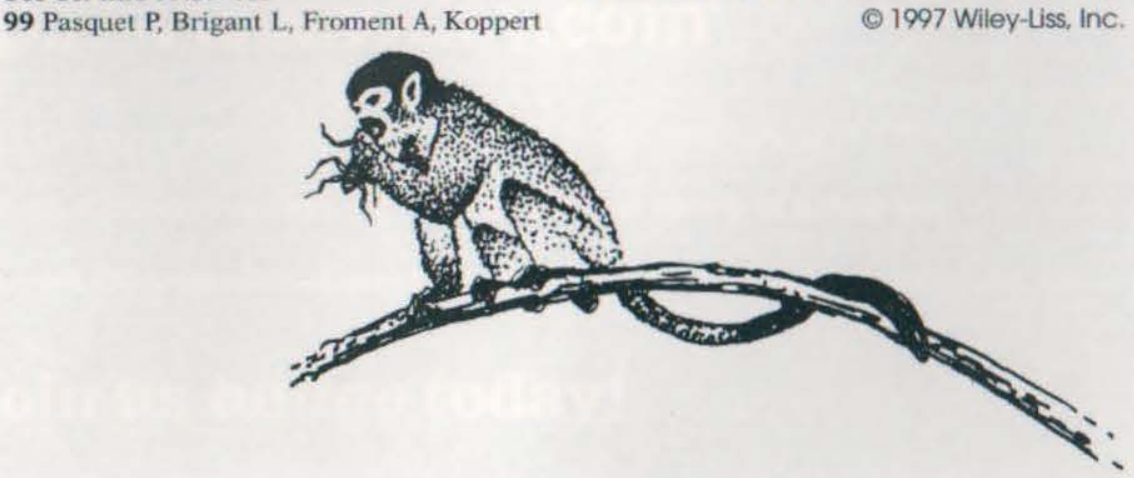

, Bard D, Garine I de, Apfelbaum M (1992)
Massive overfeeding and energy balance in 6:483-490.
100 Koshimizu K, Ohigashi H, Huffman MA (1994) Use of Vemonia amydadalina by wild ted constituents. Physiol Behav 56:1209101 Mahaney WC, Aufreiter S, Hancock RGV (1995) Mountain gorilla geophagy: A possible
seasonal behavior for dealing with the effects
fdietary changes. Int J Primatol 16:475-488. 102 Rozin P, Kalat JW (1971) Specific hungers tions of learning. Psychol Rev $70: 459-485$.
to 03 Hugh-Jones S (1993) a Fooda and edrugs
in Northwest Amazonia. In Hladik CM, Hladik , Linares OF, Pagezy H, Semple A, Hadley M
eds), Tropical Forests, People and Food: liocultural Interactions and Applications to
Development, pp 533-548. Paris: UNESCO04 Johns T (1990) With Bitter Herbs They Shall Eat It. Chemical Ecology and the Origins
Human Diet and Medicine. Tucson: The Uni105 Delluc G, Delluc B, Roques M (1995) La
Nutrition Prehistorique Périgueux: Pilote 24. 106 Goodall I (1986) The Chimpanzees of 107 Galdikas BMF, Teleki G (1981) Variations pongids: New perspectives on the origins of
hominid labor division. Curr Anthropol 108 Hladik CM (1995) Différenciation les Primates non humains et chez l'Homme.
In Ducros A, Panoff M (eds), La Frontière des 109 Clarke RJ, Tobias PV (1995) Sterkfontein can hominid Science 269:521-524. 110 Jolly CJ (1970) The seed-eaters: A new
model of hominid differentiation based on a 11 Hladik A, Dounias E (1993) Wild yams of

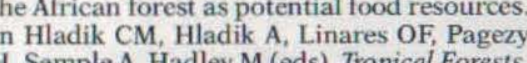
People and Food: Biocultural Intreractions and
Applications to Development, pp 163-176. Applications to Development, pp 163-176.
Paris: UNESCO-Parthenon Publishing Group. 12 Linares OF (1993) Palm oil versus palm Hadik CM. Hadik A, Linares OF Pagezy H,
Hladices
Semple A. Hadley M (eds) Tropical Forests People and Food: Biocultural Interactions and
Applications to Development, pp $595-606$. 99 Pas 